\title{
Kemampuan Menulis Karya Tulis Ilmiah Mahasiswa Prodi Informatika Universitas Cokroaminoto Palopo
}

\author{
Nirwana \& Abd. Rahim Ruspa \\ Universitas Cokroaminoto Palopo \\ Email: nirwanawan27501@gmail.com; rahim.ruspa@gmail.com
}

\begin{abstract}
Abstrak
Peneliti ini bertujuan untuk mendeskripsikan kemampuan menulis KTI pada mahasiswa Program Studi Informatika Universitas Cokroaminoto Palopo. Jenis penelitian yang digunakan yaitu deskriptif kuantitatif. Untuk menjawab pertanyaan tersebut data dianalisis dan dideskripsikan. Populasi dalam penelitian ini adalah mahasiswa semester II Program Studi Informatika Universitas Cokroaminoto Palopo. Sedangkan yang dijadikan sampel dalam penelitian ini adalah kelas II-S. Teknik yang digunakan dalam penelitian ini adalah teknik tes. Data yang terkumpul dianalisis dengan menggunakan teknik statistik deskriptif. Hasil penelitian menunjukan bahwa kemampuan menulis KTI pada mahasiswa kelas II S Program Studi Informatika Universitas Cokroaminoto Palopo dikategorikan belum memadai. Hal ini dinyatakan berdasarkan data hasil tes kemampuan mahasiswa, yaitu sebanyak 9 orang $(30,00 \%)$ yang mampu memperoleh nilai di atas 75. Sedangkan 21 orang (70,00\%) yang mendapat nilai di bawah 75. Dengan semikian, dapat dinyatakan bahwa kemampuan menulis KTI pada mahasiswa kelas II S Program Studi Informatika Universitas Cokroaminntn Palopo belum mencapai standar ketentuan belajar klasikal yang ditetapkan, yaitu 85\%.
\end{abstract}

Kata kunci: menulis; KTI

\section{Pendahuluan}

Pendidikan dapat diartikan sebagai kegiatan seseorang dalam membimbing dan memimpin anak menuju pertumbuhan dan perkembangan secara optimal agar dapat berdiri sendiri dan bertanggung jawab. Pendidikan berkaitan erat dengan segala sesuatu yang berhubungan dengan perkembangan manusia mulai perkembangan fisik, kesehatan keterampilan, pikiran, perasaan, dan kemauan sosial. Perkembangan tersebut nantinya digunakan sebagai persiapan untuk mengantisipasi perkembangan yang terjadi pada masa depan. Hal ini sejalan dengan orientasi dari pendidikan itu sendiri.

Pendidikan yang sesuai dan berkualitas adalah suatu kegiatan belajar mengajar yang didukung oleh proses pembelajaran yang efektif, peserta didik cepat memahami apa yang diajarkan, pembaharuan kurikulum, peningkatan kualitas pendidik, pengadaan sarana dan prasarana yang lengkap pada masing-masing sekolah. Dalam perkembangannya sampai saat ini, tampak jelas bahwa masalah yang serius dalam peningkatan kualitas adalah rendahnya kualitas pendidikan di berbagai jenjang pendidikan, baik pendidikan formal maupun informal.

Standar kompetensi pada aspek kemampuan berbahasa meliputi aspek menyimak, berbicara, membaca dan menulis. Keempat aspek keterampilan 
tersebut menjadi faktor pendukung dalam menyampaikan pikiran, gagasan dan pendapat baik secara tertulis maupun secara lisan. Sesuai konteks komunikasi yang harus dikuasai oleh pemakai bahasa. Dengan menguasai empat aspek berbahasa tersebut, tujuan umum pembelajaran bahasa dapat tercapai.

Menulis adalah proses menuangkan ide dalam bentuk tulisan berupa informasi yang disampaikan kepada orang lain, menulis juga merupakan salah satu aspek penting dalam proses komunikasi karena dengan tulisan yang baik maka akan dengan mudah isi pesan yang terkandung dalam tulisan itu dipahami oleh pembaca. Namun pada saat pelaksanaan pembelajaran, kegiatan menulis seringkali menjadi pembelajaran yang dirasakan sulit bagi mahasiswa.

Dalam penulisan karya tulis ilmiah, mahasiswa seringkali mengalami kesulitan pada penguasaan kosakata dan tata bahasa. Kesulitan mendapatkan ide atau gagasan pun selalu menjadi hambatan, padahal dalam menulis sebuah KTI penulis dituntut harus memiliki ide atau gagasan serta kosakata yang memadai dan berhubungan dengan tema yang akan diangkat dalam menulis. Pada hakikatnya semua orang pasti memiliki sejumlah ide dalam benaknya. Namun, kebanyakan mahasiswa kurang mampu menuangkan ideidenya dan mengembangkan ide tersebut menjadi sebuah paragraf yang kemudian menjadi sebuah tulisan yang baik.

\section{Tinjauan Pustaka Menulis}

Beberapa definisi menulis yang dikemukakan oleh para ahli sangat beragam. Menulis merupakan keterampilan berbahasa yang harus dipelajari secara terus menerus. Tulisan yang baik adalah tulisan yang dapat memberikan informasi kepada pembaca secara jelas. Menurut Tarigan (2013) menulis adalah menurunkan atau melukiskan lambang lambang grafis yang menghasilkan suatu bahasa yang dapat dipahami oleh seseorang sehingga orang lain dapat membaca lambing lambing grafis tersebut dan dapat memahami bahasa dan grafis itu. Menurut Suparno dan Yunus (2003:13) aktivitas menulis melibatkan beberapa unsur, yaitu penulis sebagai penyampaian pesan, isi tulisan, saluran atau media, dan pembaca. Menulis merupakan suatu kegiatan penyampaian pesan (komunikasi) dengan menggunakan bahasa tulis sebagai alat atau medianya.

Berdasarkan uraian di atas dapat disimpulkan bahwa menulis merupakan suatu proses aktivitas gagasan, pikiran, perasaan yang ingin disampaikan kepada orang lain melalui media bahasa yang berupa tulisan. Sebagai alat komunikasi tidak langsung melalui tulisan penulis dapat mendeskripsikan sesuatu kepada orang lain sehingga pembaca dapat melukiskan apa yang disampaikan. Semakin baik tulisan yang disampaikan semakin baik pula pesan yang diterima oleh orang lain.

Tarigan (2013) mengemukakan bahwa tujuan menulis ialah (1) tujuan penugasan, yaitu penulis menulis sesuatu karena ditugaskan, bukan karena kemauan sendiri, (2) tujuan altruistic, yaitu bertujuan untuk menyenangkan 
pembaca menghindarkan kedukaan para pembaca,ingin mendorong pembaca memahami, ingin mendorong pembaca memahami, ingin membuat hidup para pembaca, lebih menyenangkan dengan karyanya itu, (3) tujuan persuasive, yaitu tulisan yang bertujuan untuk meyakinkan para pembaca dengan kebenaran yang diutarakan, (4) tujuan informational, tujuan penerangan, yaitu tulisan yang bertujuan untuk memberi informasi atau keterangan/penerangan kepada pembaca, (5) tujuan pernyataan, diri, yaitu tulisan yang bertujuan untuk memperkenalkan atau menyatakan diri sebagai sang pengarang kepada pembaca, (6) tujuan kreatif, yaitu tulisan yang bertujuan untuk mencapai nilai-nilai artistic dan nilai nilai kesenian, (7) tujuan pemecahan masalah, yaitu tulisan yang bertujuan untuk mencerminkan atau menjelajahi pikiran-pikiran agar dapat dimengerti pembaca.

\section{Karya Tulis Ilmiah (KTI)}

Karya tulis ilmiah adalah karangan yang memaparkan pendapat, hasil pengamatan, tinjauan, dan penelitian dalam bidang tertentu yang disusun menurut metode tertentu dengan sistematika penulisan, bersantun bahasa, dan isi yang kebenarannya dapat dipertanggungjawabkan. Sedangkan menurut Suriasumantri (1995) dalam Finoza (2010), karya tulis ilmiah adalah tulisan yang memuat argumentasi penalaran keilmuan serta dikomunikasikan lewat bahasa tulisan yang baku dengan sistematis-metodis dan sintesis analitis.

Pengertian karya ilmiah menurut para ahli dalam Finoza (2010):

1. Menurut Eko Susilo (1995) karya ilmiah adalah salah satu karangan atau tulisan yang didapat sesuai sifat keilmuannya dan didasari oleh hasil pengamatan, pemantauan, penelitian dalam bidang tertentu, disusun menurut metode tertentu serta sistematika penulisan yang bersantun bahasa dan isinya dapat dipertanggungjawabkan kebenarannya atau keilmiahannya.

2. Menurut Dwiloka dan Riana, karya ilmiah atau artikel ilmiah merupakan karya seorang ilmuwan (pembangunan) yang hendak membangun ilmu pengetahuan, teknologi, dan seni yang didapat melalui literatur, pengalaman, serta penelitian.

3. Pengertian karya tulis ilmiah menurut KBBI merupakan karya tulis yang dibuat menggunakan prinsip-prinsip ilmiah dan berdasarkan fakta (observasi, eksperimen, dan kajian pustaka).

Dapat disimpulkan karya tulis ilmiah adalah laporan tertulis diterbitkan yang mengungkapkan hasil penelitian atau pengkajian yang dilakukan oleh seseorang atau tim dengan memenuhi kaidah serta etika keilmuan yang ditaati oleh masyarakat keilmuan.

Jenis-Jenis Karya Tulis Ilmiah

Arifin (2003) mengatakan bahwa ada beberapa jenis karangan ilmiah yang biasa ditulis orang. Selain makalah dan skripsi, ada pula nama lain, seperti kertas kerja, laporan penelitian, tesis dan disertasi. Berikut jenis-jenis karya ilmiah menurut Arifin (2003):

a. Makalah 
Makalah adalah karya tulis ilmiah yang mengutarakan suatu masalah dan pembahasannya berdasarkan data di lapangan yang bersifat empirisobjektif. Menurut KBBI, makalah adalah tulisan resmi suatu pokok dengan tujuan untuk dibacakan di muka umum dalam suatu persidangan serta disusun untuk diterbitkan dan juga merupakan karya tulis pelajar atau mahamahasiswa untuk laporan hasil pengerjaan tugas sekolah atau perguruan tinggi.

b. Kertas kerja

Kertas kerja hampir sama dengan makalah, namun penjabaran untuk kertas kerja lebih mendetail daripada makalah. Menurut KBBI kertas kerja adalah karangan tertulis yang membahas masalah tertentu yang disampaikan dalam suatu seminar untuk mendapat jawaban lebih lanjut.

c. Skripsi

Skripsi adalah karya tulis ilmiah yang ditulis menurut pendapat orang lain dan diri sendiri. Data diperoleh melalui observasi lapangan atau percobaan laboratorium. Menurut KBBI skripsi ialah tulisan saintifik yang wajib dibuat oleh mahamahasiswa sebagai persyaratan akhir pendidikannya.

d. Tesis

Tesis adalah karya ilmiah yang menyajikan temuan baru dengan melakukan penelitian sendiri. Tesis ini juga adalah tulisan yang lebih mendetail daripada skripsi. Menurut KBBI tesis merupakan pernyataan yang didukung oleh argumen yang disajikan dalam bentuk karangan untuk memperoleh gelar sarjana pada perguruan tinggi dan merupakan karangan ilmiah yang dibuat untuk mendapatkan gelar sarjana pada suatu universitas (perguruan tinggi).

e. Disertasi

Disertasi adalah karya ilmiah yang menyajikan suatu dalil dan dibuktikan sendiri oleh penulis. Disertasi ini disusun sebagai tugas akhir untuk meraih gelar doktor. Menurut KBBI disertasi merupakan karangan ilmiah yang dibuat guna mendapatkan gelar doktor.

\section{Sistematika dan Struktur Karya Ilmiah}

Dalam pembuatan karya ilmiah yang memenuhi kaidah penulisan terdapat sistematika atau struktur yang menjadi poin penting. Tidak hanya menyusun sebuah berita yang memiliki sistematika, namun karya tulis ilmiah pun memiliki sistematika atau urutan. Menurut Finoza (2010), karya ilmiah menaati kaidah atau aturan penulisan secara ketat dan sistematis.

Kemudian, tulisan saintifik ini memiliki tata bentuk yang dibagi menjadi tiga bagian, yaitu:

a. halaman-halaman awal (preliminaries) yang mencakup judul, kata pengantar, aneka daftar seperti daftar isi, dan daftar tabel/bagan/lampiran,

b. isi utama (main body) yang mencakup pendahuluan, isi dan penutup, serta

c. halaman-halaman akhir (reference-matter) yang mencakup daftar pustaka, lampiran, dan biodata penulis. 
Pengelompokkan tiga bagian karya ilmiah juga diungkapkan oleh Arifin (2003) antara lain, bagian pembuka karangan ilmiah, bagian inti karangan ilmiah, dan bagian penutup karangan ilmiah. Tiga bagian tersebut dirinci lagi menjadi sebagai berikut.

Bagian pembuka terdiri atas 9 bagian yaitu:

1. Kulit luar

2. Halaman judul

3. Halaman pengesahan (jika perlu)

4. Halaman penerimaan (jika perlu)

5. Kata Pengantar

6. Daftar isi

7. Daftar tabel (jika ada)

8. Daftar gambar (jika ada)

9. Daftar singkatan dan lambang (jika ada)

Untuk bagian inti terdapat tiga bagian, antara lain:

1. Bab pendahuluan

2. Bab analisis atau pembahasan

3. Bab simpulan

Bagian penutup juga terdiri dari tiga bagian, yaitu:

1. Daftar pustaka

2. Indeks (jika perlu)

3. Lampiran (jika perlu)

\section{Metode Penelitian}

\section{Jenis Penelitian}

Jenis penelitian ini merupakan jenis penelitian deskripsi kuantitatif. Penelitian yang berjudul "Kemampuan Menulis KTI Program Studi Informatika Universitas Cokroaminoto Palopo".

\section{Populasi dan Sampel}

Populasi dalam penelitian ini adalah seluruh mahamahasiswa Program Studi Informatika Universitas Cokroaminoto Palopo tahun ajaran 2019/2020. Teknik pengambilan sampel dalam penelitian ini menggunakan teknik sampling acak (cluster random sampling). Adapun sampel dalam penelitian ini adalah mahamahasiswa kelas II S Program Studi Informatika Universitas Cokroaminoto Palopo.

\section{Definisi Operasional Variabel}

Definisi operasional adalah batasan pengertian yang dijadikan pedoman dalam melakukan suatu kegiatan atau pekerjaan.

1. Kemampuan adalah salah satu unsur dalam kematangan berkaitan dengan pengetahuan atau keterampilan yang dapat diperoleh dari pembelajaran, pelatihan. pengalaman.

2. Menulis KTI adalah suatu kegiatan mengungkapkan gagasa, pikiran, pengalaman dan pengetahuan kedalam bentuk catatan dengan 
menggunakan aksara, lambang atau simbol yang dibuat secara sistematis sehingga dapat dengan mudah dipahami orang lain.

\section{Teknik Pengumpulan Data}

Teknik pengumpulan data dalam penelitian ini adalah tes. Tes yang diberikan yaitu menulis KTI. Tes yang diberikan kepada mahasiswa dikerjakan dalam waktu 2x50 menit. Waktu yang dipergunakan disesuaikan dengan jam pelajaran mata kuliah penulisan ilmiah.

\section{Teknik Analisis Data}

Setelah semua data terkumpul, langkah-langkah analisis terhadap datadata yang telah ada dilakukan. Dilakukannya pemberian nilai terhadap hasil mahasiswa dalam instrumen berdasarkan kriteria penilaian yang telah dipaparkan. Setelah kemampuan diketahui, maka kategorisasi kemampuan mahasiswa dapat pula diketahui.

Hasil penelitian ini berupa bahan yang diperoleh dari sampel dan analisis dengan menggunakan teknik statistik deskriptif. Langkah-langkah dalam menganalisis data adalah sebagai berikut:

\section{Analisis Data Deskriptif}

Statistik deskriptif adalah statistik yang digunakan untuk menganalisis data dengan cara mendeskripsikan atau menggambarkan data yang telah terkumpul sebagaimana adanya tanpa bermaksud membuat kesimpulan yang berlaku untuk umum atau generalisasi (Sugiyono, 2016:207). Dalam penelitian ini, analisis statistik deskriptif digunakan untuk mendeskripsikan hasil belajar menulis pengalaman pribadi pada setiap mahasiswa.

Untuk mengetahui hasil belajar kemampuan menulis teks berita setelah penerapan pendekatan kontekstual, digunakan kriteria sebagai berikut:

Tabel Tingkat penguasaan materi dan kategorinya

\begin{tabular}{llll}
\hline Skor & Kategori & Frekuensi & Persentase \\
\hline $0 \%-54 \%$ & Sangat rendah & & \\
$55 \%-64 \%$ & Rendah & \\
$65 \%-74 \%$ & Sedang & \\
$75 \%-89 \%$ & Tinggi & \\
$90 \%-100 \%$ & Sangat tinggi & \\
\hline
\end{tabular}

Tabel Hasil kriteria penilaian

\begin{tabular}{llll}
\hline No & Perolehan Nilai & Frekuensi & Persentase (\%) \\
\hline 1 & Nilai $\geq 75$ & Tuntas & \\
2 & Nilai $<75$ & Tidak Tuntas & \\
\hline & Jumlah & & \\
\hline
\end{tabular}

Sampel dikatakan tuntas jika memperoleh nilai 75 dan dianggap tidak tuntas jika sampel memperoleh nilai kurang dari 75.

\section{Hasil Penelitian dan Pembahasan Hasil Penelitian}

Pada bagian ini diuraikan hasil penelitian kemampuan menulis KTI Program Studi Informatika Universitas Cokroaminoto Palopo. Data yang 
diperoleh yaitu data hasil menulis KTI pada mahamahasiswa kelas II S Program Studi Informatika Universitas Cokroaminoto Palopo.

Berdasarkan analisis data tes kemampuan menulis KTI pada mahamahasiswa kelas II S Program Studi Informatika Universitas Cokroaminoto Palopo dengan 30 orang diperoleh gambar, yaitu: tidak ada mahasiswa yang mampu memperoleh skor 100 sebagai skor maksimal. Skor tertinggi hanya 95 yang diperoleh 1 orang dan skor terendah adalah 50 yang di peroleh oleh 1 orang.

Gambaran yang lebih jelas dan tersusun rapi dari skor tertinggi sampai dengan skor terendah yang diperoleh mahasiswa beserta frekuensinya dalam menulis KTI pada mahamahasiswa kelas II S Program Studi Informatika Universitas Cokroaminoto Palopo.

Tabel Distribusi Frekuensi dan Persentase Skor

\begin{tabular}{llll}
\hline No & Skor Mentah & Frekuensi & Persentase (\%) \\
\hline 1 & 95 & 2 & 6,67 \\
2 & 92 & 2 & 6,67 \\
3 & 87 & 2 & 6,67 \\
4 & 80 & 1 & 3,33 \\
7 & 75 & 2 & 6,67 \\
10 & 67 & 6 & 20 \\
12 & 65 & 6 & 20 \\
13 & 60 & 5 & 16,67 \\
16 & 55 & 3 & 10 \\
17 & 50 & 1 & 3,33 \\
\hline Jumlah & & 30 & 100 \\
\hline
\end{tabular}

Sumber: Analisis Data Primer (2020)

Berdasarkan Tabel Distribusi Frekuensi dan Persentase Skor tersebut dapat diketahui bahwa skor tertinggi yang diperoleh mahasiswa yaitu 95 yang diperoleh 2 orang $(6,67 \%)$. Selanjutnya sampel yang mendapat skor 92 berjumlah 2 orang (6,67\%); sampel yang mendapat skor 87 berjumlah 2 orang $(6,67 \%)$; sampel yang mendapat skor 80 berjumlah 1 orang $(3,33 \%)$; sampel yang mendapat skor 75 berjumlan 2 orang $(6,67 \%)$; sampel yang mendapat skor 67 berjumlah 6 orang (20,00\%); sampel yang mendapat skor 65 berjumlah 6 orang (20,00\%); sampel yang mendat skor 60 berjumlah 5 orang (16,57\%); sampel yang mendapat skor 55 berjumlah 3 orang $(10 \%)$; dan sampel yang mendapat skor 50 berjumlah 1 orang 3,33\%).

Berdasarkan perolehan skor, frekuensi, dan presentase kemampuan menulis KTI pada mahamahasiswa kelas II S Program Studi Informatika Universitas Cokroaminoto Palopo dapat pula diketahui distribusi nilai, frekuensi, dan presentasenya. Distribusi nilai, frekuensi, dan persentase tersebut sangat membantu dan mempermudah dalam memperoleh nilai secara keseluruhan kemampuan menulis KTI pada mahamahasiswa kelas II S Program Studi Informatika Universitas Cokroaminoto Palopo.

Hasil rata-rata mahasiswa tersebut dapat dikonversi ke dalam tabel klasifikasi tingkat hasil belajar mahasiswa. Untuk mengetahui tingkat hasil belajar menulis pengalaman pribadi dapat dilihat pada tabel berikut. 
Tabel Klasifikasi Kemampuan Hasil Belajar

\begin{tabular}{ccccc}
\hline No & Kategori & Interval & Frekuensi & Persentase (\%) \\
\hline 1 & Sangat Rendah & $0-54$ & 1 & 3,33 \\
2 & Rendah & $55-64$ & 8 & 26,67 \\
3 & Sedang & $65-74$ & 12 & 40,00 \\
4 & Tinggi & $75-89$ & 5 & 16,67 \\
5 & Sangat Tinggi & $90-100$ & 4 & 13,33 \\
\hline & Jumlah & 30 & 100 \\
\hline
\end{tabular}

Sumber: Analisis Data Primer (2020)

Berdasarkan Tabel klasifikasi tingkat hasil belajar menulis pengalaman pribadi dapat diketahui bahwa mahasiswa yang mendapat skor 0-54 sebanyak 1 dengan kategori sangat rendah, mahasiswa yang mendapat skor 55-64 sebanyak 8 dengan kategori rendah, mahasiswa yang mendapat skor 65-74 sebanyak 12 dengan kategori sedang, mahasiswa yang mendapat skor 75-89 sebanyak 5 dengan kategori tinggi dan mahasiswa yang mendapat skor 90-100 sebanyak 4 dengan kategori sangat baik. Hal ini menunjukan bahwa tingkat kemampuan dilihat dari klasifikasi tingkat hasil belajar dan persentase pada pembelajaran menulis KTI pada mahamahasiswa kelas II S Program Studi Informatika Universitas Cokroaminoto Palopo.

Sesuai dengan hasil analisis data tersebut dapat dikonfirmasikan ke dalam kriteria kemampuan yang telah di tetapkan, yaitu mahasiswa dinyatakan mampu apabila jumlah mahasiswa mencapai 85\% yang memperoleh nilai 75 ke atas. Sebaliknya, mahasiswa dinyatakan tidak mampu apabila jumlah mahasiswa kurang dari 85\% yang memperoleh nilai kurang dari 75. Untuk menggambarkan pernyataan ini, dapat dilihat pada tabel berikut ini.

Tabel Klasifikasi Kemampuan

\begin{tabular}{llll}
\hline No & Skala Nilai & Frekuensi & Persentase \\
\hline 1 & Nilai 75 ke atas & 9 & 30,00 \\
2 & Nilai di bawah 75 & 21 & 70,00 \\
\hline Jumlah & 30 & 100 \\
\hline
\end{tabular}

Sumber: Analisis Data Primer

Berdasarkan Tabel klasifikasi kemampuan di atas, diketahui frekuensi dan presentase nilai kemampuan menulis KTI pada mahamahasiswa kelas II S Program Studi Informatika Universitas Cokroaminoto Palopo, yaitu 9 orang $(30,00 \%)$ yang mampu mendapat nilai 75 ke atas . Sebaliknya, sebanyak 21 orang $(70,00)$ mendapat nilai di bawah 75 . Dengan demikian, dapat dinyatakan bahwa kemampuan menulis KTI pada mahamahasiswa kelas II S Program Studi Informatika Universitas Cokroaminoto Palopo dikategorikan belum memadai, karena mahasiswa memperoleh nilai 75 ke atas tidak mencapai kriteria yang ditetapkan, yaitu $85 \%$.

\section{Pembahasan}

Berdasarkan penyajian hasil analisis data, dapat diuraikan temuan penelitian ini tentang kemampuan menulis KTI pada mahamahasiswa kelas II 
S Program Studi Informatika Universitas Cokroaminoto Palopo. Kemampuan menulis KTI pada mahamahasiswa kelas II S Program Studi Informatika Universitas Cokroaminoto Palopo diukur berdasarkan indikator penilaian karya tulis ilmiah, yaitu kesesuaian judul dengan isi, organisasi isi, sistematika penulisan, penggunaan bahasa dan ejaan.

Hasil penelitian pada menulis KTI pada mahamahasiswa kelas II S Program Studi Informatika Universitas Cokroaminoto Palopo dikategorikan belum memadai atau belum mampu. Hal ini menunjukkan kemampuan mahasiswa belum mencapai kriteria ketuntasan minimal yaitu 75 ke atas. Kemampuan mahasiswa berdasarkan data yang diperoleh bahwa mahasiswa belum mampu menciptakan ide dan gagasan lalu dituangkan dalam wujud tulisan berupa KTI.

Hasil data temuan menunjukkan bahwa hasil menulis KTI diperoleh jumlah mahasiswa yang mampu menulis karya tulis ilmiah,yaitu 9 orang $(30,00 \%)$ dari total 30 mahasiswa, sedangkan jumlah mahasiswa yang tidak mampu menulis karya tulis ilmiah, yaitu 21 orang $(70,00 \%)$ dari total 30 mahasiswa.

Berdasarkan hasil temuan yang telah didapatkan dari data menulis KTI pada mahamahasiswa kelas II S Program Studi Informatika Universitas Cokroaminoto Palopo, maka dapat disimpulkan bahwa mahamahasiswa kelas II S Program Studi Informatika Universitas Cokroaminoto Palopo, belum mampu menulis karya tulis ilmiah secara baik.. Hal itu terlihat dari nilai ratarata yang dicapai yaitu $69,50 \%$. Hasil penelitian ini menunjukkan bahwa kemampuan mahasiswa dalam menuliskan KTI belum mampu.

\section{Simpulan}

Berdasarkan penyajian hasil analisis data dan pembahasan dapat disimpulkan, yaitu kemampuan menulis KTI pada mahamahasiswa kelas II S Program Studi Informatika Universitas Cokroaminoto Palopo dinyatakan belum mampu. Hal ini dinyatakan berdasarkan data hasil tes kemampuan mahasiswa, yaitu sebanyak 21 orang $(70,00 \%)$ mendapat nilai kurang dari 75 dan senayak 9 mahasiswa mendat nilai 75 ke atas. Sebaliknya, mahasiswa dinyatakan tidak mampu apabila jumlah mahasiswa kurang dari 85\% yang memperoleh nilai kurang dari 75 dan nilai rata-rata yang diperoleh yaitu 69,50. Dengan demikian, dapat dinyatakan bahwa kemampuannya menulis KTI pada mahamahasiswa kelas II S Program Studi Informatika Universitas Cokroaminoto Palopo tidak mencapai Standar Ketuntasan Belajar Minimum (SKBM) yang ditetapkan, yaitu 85\%. 
Jurnal Onoma: Pendidikan, Bahasa dan Sastra PBSI FKIP Universitas Cokroaminoto Palopo

Volume 6 Nomor 1
ISSN 2443-3667 (print)

ISSN 2715-4564 (online)

\section{Daftar Pustaka}

Arikunto, Suharsimi. 2010. Managemen Penelitian. Jakarta: Rineka Cipta.

Dalman. 2015. Keterampilan Menulis. Depok: Rajawali Pers.

Finoza, Lamuddin. 2010. Komposisi Bahasa Indonesia. Jakarta: Diksi Insan Media.

Sugiyono. 2016. Metode Penelitian Kuantitatif Kualittatif dan R\&d. Bandung. Alfabeta.

Suparno dan Muhammad Yunus. 2003. Keterampilan Dasar Menulis. Jakarta: Unversitas Terbuka.

Tarigan, Hendry Guntur. 2013. Menulis Sebagai Suatu Keterampilan Berbahasa. Bandung: Angkasa. 